DOI 10.31558/2307-2318.2018.3.3

УДК 331.101.52:330.341.1:005.21

Лісогор Л.С., д.е.н., професор, Інститут демографії та соціальних досліджень імені М.В. Птухи НАН України

Руденко Н.В., к.е.н., Київський національний університет імені Тараса Шевченка

Чувардинський B.O., аспірант, Київський національний університет імені Тараса Шевченка

\title{
КОНКУРЕНТОСПРОМОЖНІСТЬ РОБОЧОЇ СИЛИ: ПРОБЛЕМИ ФОРМУВАННЯ ТА РЕАЛІЗАЦІЇ В УМОВАХ ІННОВАЦЙНИХ ЗМІН НА РИНКУ ПРАЦІ
}

У статті комплексно досліджено умови підвищення конкурентоспроможності робочої сили, зокрема необхідність постійного оновлення знань, умінь, навичок, формування сприятливого соціально-психологічного клімату та відповідних умов праці. Доведено, що пріоритетного значення в умовах глобалізації набувають інноваційні чинники розвитку, пов'язані із забезпеченням технологічного оновлення виробництва, підвищенням ступеню готовності робочої сили до інноваційних змін. Обгрунтовано можливість досягнення високого рівня конкурентоспроможності національних економік за рахунок мобілізації чинників ефективності та інноваційності, створення умов для реалізації конкурентних переваг робочої сили на внутрішньому та зовнішньому ринках праці. Досліджено специфіку формування та реалізації конкурентних переваг робочої сили, обумовлену особливостями характеру та змісту праці, у процесі якого використовуються споживчі якості робочої сили. Доведено, що формування конкурентних переваг робочої сили пов'язано з існуючим демографічним, трудовим та соціальним потенціалами окремих індивідів та населення у цілому, а також можливостями їх ефективного використання та розвитку. Обгрунтовано, що посилення ролі творчого характеру праці в умовах інноваційних змін (при зниженні значимості жорстко регламентованої, уніфікованої праці) обумовлює відповідні зміни у співвідношенні способів отримання конкурентних переваг. В ході дослідження визначено залежність між способом реалізації конкурентних переваг робочої сили та співвідношенням попиту та пропозиції. Розроблено структурно-логічну схему формування та реалізації конкурентоспроможності робочої сили на основі реалізації цінових та нецінових конкурентних переваг. Проаналізовано вплив демографічних, техніко-організаційних, соціально-економічних, освітньо-професійних та особистісномотиваційних чинників на формування та реалізацію конкурентоспроможності робочої сили. Розроблено систему заходів, спрямованих на запобігання трансформації ризиків формування та реалізації конкурентоспроможності робочої сили у загрози. У якості перспектив подальших досліджень запропоновано розроблення механізму забезпечення реалізації конкурентних переваг робочої сили, дослідження синергетичного ефекту від дії чинників впливу на формування та реалізацію конкурентоспроможності робочої сили.

Ключові слова: конкурентоспроможність робочої сили, конкурентні переваги, ринок праці, ризики, інноваційні чинники. 


\section{Лисогор Л.С., Руденко Н.В., Чувардинский В.А. КОНКУРЕНТОСПОСОБНОСТЬ РАБОЧЕЙ СИЛЫ: ПРОБЛЕМЫ ФОРМИРОВАНИЯ И РЕАЛИЗАЦИИ В УСЛОВИЯХ ИННОВАЦИОННЫХ ИЗМЕНЕНИЙ НА РЫНКЕ ТРУДА}

В статье комплексно исследовано условия повышения конкурентоспособности рабочей силы, необходимость постоянного обновления знаний, умений, навыков, формирования благоприятного социально-психологического климата и соответствующих условий труда. Доказано, что в условиях глобализации приоритетное значение приобретают инновационные факторы развития, связанные с обеспечением технологического обновления производства, повышением степени готовности рабочей силы к инновационным изменениям. Обоснована возможность достижения высокого уровня конкурентоспособности национальных экономик за счет мобилизации факторов эффективности и инновационности, создания условий для реализации конкурентных преимуществ рабочей силы на внутреннем и внешнем рынках труда. Исследована специфика формирования и реализации конкурентных преимуществ рабочей силы, обусловленная особенностями характера и содержания труда, в процессе которого используются потребительские качества рабочей силы. Доказано, что формирование конкурентных преимуществ рабочей силы связано с существующим демографическим, трудовым и социальным потенциалами отдельных индивидов и населения в целом, а также возможностями их эффективного использования и развития. Обосновано, что усиление роли творческого характера труда в условиях инновационных изменений (при снижении значимости жестко регламентированного, унифицированного труда) обусловливает соответствующие изменения в соотношении способов получения конкурентных преимуществ. В ходе исследования определена зависимость между способом реализации конкурентных преимуществ рабочей силы и соотношением спроса и предложения. Разработана структурно-логическая схема формирования и реализации конкурентоспособности рабочей силы (на основе реализации ценовых и неценовых конкурентных преимуществ). Проанализировано влияние демографических, технико-организационных, социально-экономических, образовательнопрофессиональных и личностно-мотивационных факторов на формирование и реализацию конкурентоспособности рабочей силы. Разработана система мероприятий, направленных на предотвращение трансформации рисков формирования и реализации конкурентоспособности рабочей силы в угрозы. В качестве перспективных исследований предложена разработка механизма обеспечения реализации конкурентных преимуществ рабочей силы, исследования синергетического эффекта от действия факторов влияния на формирование и реализацию конкурентоспособности рабочей силы.

Ключевые слова: конкурентоспособность рабочей силы, конкурентные преимущества, рынок труда, риски, инновационные факторы.

\section{Lisogor L.S., Rudenko N.V., Chuvardynskyy V.O. COMPETITIVENESS OF LABOUR FORCE: PROBLEMS OF THE FORMATION AND REALIZATION UNDER CONDITIONS OF INNOVATIVE CHANGES AT LABOUR MARKET}

The article investigates the conditions for increasing the competitiveness of the labour force, in particular the need for updating of knowledge, skills, qualifications and the formation of a favorable socio-psychological climate and appropriate working conditions. It is 
proved that the innovative factors of development connected with providing of the technological upgrading of production, increasing the readiness of labour force to innovate changes became the priorities under globalization. The possibility of achieving a high level of competitiveness of national economies based on the mobilization of efficiency and innovation factors, creation of the conditions for realization of competitive advantages of the labour force at the domestic and foreign labour markets is substantiated. The specific features of the formation and implementation of competitive advantages of the labour force, determined by the peculiarities of the nature and content of labor, in which the consumer qualities of the labour force are used, are investigated. It is proved that the formation of competitive advantages of the labour force is connected with the existing demographic, labour and social potential of individual individuals and the population as a whole, as well as opportunities for their effective using and development. It is substantiated that strengthening the role of the creative nature of labour in the conditions of innovative changes (with a decrease in the importance of strictly regulated, unified labor) causes the corresponding changes in the ratio of methods of obtaining competitive advantages. During research, the dependence between the way of realizing the competitive advantages of the labour force and the ratio of demand and supply had been determined. The structural-logical scheme of formation and realization of labour competitiveness is developed on the basis of realization of price and non-price competitive advantages. The influence of demographic, technical and organizational, socioeconomic, educational and professional and individual and incentive factors on formation and realization of labour competitiveness is analysed. A system of measures aimed at preventing the transformation of the risks of the formation and implementation of the competitiveness of the labour force into a threat has been developed. As prospects for further researches, it is proposed to develop a mechanism for ensuring the realization of competitive advantages of a workforce, studying the synergistic effect from the influence of factors of influence on the formation and implementation of the competitiveness of the labour force.

Key words: competitiveness of labour force, competitive advantages, labour market, risks, innovative factors.

Постановка проблеми. Посилення глобалізаційних тенденцій розвитку світової економіки обумовлює необхідність пошуку країнами найбільш ефективних моделей економічного розвитку, пов'язаних 3 отриманням та реалізацією конкурентоспроможних переваг інноваційного типу. Серед найважливіших пріоритетів суспільного розвитку, затверджених у 2014 році Європарламентом, Радою Європи, Європейським Соціально-Економічним Комітетом та Комітетом Регіонів Комюніке комісії «Про Свропейське Індустріальне Відродження» ('For a European Industrial Renaissance". Communication from the Commission to the European Parliament, the Council, the European Economic and Social Committee and the Committee of the Regions), було відзначено необхідність модернізації промисловості для створення робочих місць; сприяння конкурентоспроможності та інноваціям, розвитку навичок та підприємництва; поліпшення можливостей навчання та підвищення мобільності населення [1]. Прийнята країнами «Великої Двадцятки» Стратегія «Кваліфікована робоча сила для потужного, сталого та збалансованого зростання» (A G20 Training Strategy "A Skilled Workforce for Strong, Sustainable and Balanced Growth") також передбачала швидке реагування систем освіти та навчання економічно розвинених країн на зміни вимог до кваліфікацій, обумовлені прискоренням технологічного прогресу та поширенням інновацій [2]. 
Недооцінка важливості інноваційних чинників забезпечення конкурентоспроможності економіки може призвести до «звуження» спеціалізації менш економічно розвинених країн, консервації їх технологічного відставання від країнінноваторів. Обмеження можливостей підвищення інноваційної активності економіки може дестимулюючим чином впливати на якісні характеристики робочої сили, загострюючи ризики погіршення якості освіти, декваліфікації, збільшення масштабів міграційного відтоку економічно активного населення.

В умовах глобалізації пріоритетного значення набувають інноваційні чинники розвитку, пов'язані не тільки із забезпеченням технологічного оновлення виробництва, але й підвищенням ступеню готовності робочої сили до інноваційних змін. Передусім, це обумовлює необхідність створення умов для підвищення конкурентоспроможності робочої сили на основі використання конкурентних переваг, пов'язаних з поліпшенням iii якісних параметрів. Саме тому наукова спільнота продовжує досліджувати проблеми конкурентоспроможності робочої сили, орієнтуючись на визначення шляхів та напрямів іiі забезпечення в умовах інноваційних змін.

Аналіз останніх досліджень і публікацій. Останнім часом вітчизняні та зарубіжні науковці приділяли достатньо уваги дослідженню еволюції економічного змісту конкурентоспроможності робочої сили в умовах трансформаційних змін. Зокрема, найбільш значимий внесок у розвиток теорії конкурентоспроможності робочої сили внесли такі вітчизняні вчені-економісти як Д.П. Богиня, I.А. Войналович, Н.М. Глевацька, О.А. Грішнова, Е.М. Лібанова, М.О. Кримова, Л.Б. Мартинова, І.Л. Петрова, М.В. Семикіна, Л.В. Шаульська, І.О. Штундер. Серед зарубіжних дослідників проблем конкурентоспроможності, конкурентних переваг необхідно відзначити, у першу чергу, таких науковців як Дж. Альбрехт (J. Albrecht), Ю. Ванхала (J. Vanhala), С. Вроман (S. Vroman), Ж. Ламбен (J. Lambin), M. Портер (M. Porter), К. Сала-i-Mартін (Xavier Sala-iMartin), H. Хоффман (N. Hoffman).

Аналізуючи можливості підвищення конкурентоспроможності національних економік, Дж. Альбрехт та С. Вроман серед найбільш важливих конкурентних переваг працівників на сучасному ринку праці відзначали високий рівень кваліфікації, що забезпечує можливість зайнятості на конкурентоспроможних робочих місцях [3]. Ю. Ванхала у ході дослідження "Labor Market Frictions, Technological Change and Macroeconomic Fluctuations" підтвердив гіпотезу стосовно необхідності систематичного оновлення знань та кваліфікацій працівників, оскільки в сучасних умовах зростання продуктивності нового капіталу залежить у більшій мірі від рівня навиків, ніж від рівня витрат на робочу силу [4].

Переважна більшість науковців досліджувала еволюцію економічного змісту категорії «конкурентоспроможність робочої сили» у контексті формування економіки знань, орієнтуючись, насамперед, на визначення якісних аспектів забезпечення конкурентоспроможності. Характеризуючи особливості формування та реалізації конкурентоспроможності робочої сили в умовах обмеженості ресурсів, І.О. Штундер зазначала, що конкурентоспроможність робочої сили можна визначити як результат ії розвитку, котрий досягається через застосування комплексу заходів, що охоплює професійне навчання, перепідготовку, підвищення кваліфікації кадрів, а також планування кар'єри працівників. Серед найбільш важливих умов підвищення конкурентоспроможності робочої сили було відзначено необхідність постійного оновлення знань, умінь, навичок, формування сприятливого соціально-психологічного клімату та відповідних умов праці, покращення соціального забезпечення працівників, поліпшення показників морального та фізичного здоров'я [5, с. 202]. Загалом, це 
свідчить про існування значного наукового інтересу до питань конкурентоспроможності людського чинника, забезпечення можливостей реалізації конкурентних переваг робочої сили.

Однак дотепер недостатньо дослідженими залишаються питання, пов'язані iз забезпеченням реалізації конкурентних переваг робочої сили задля підвищення рівня іiі конкурентоспроможності у контексті інноваційних трансформацій. Це актуалізує необхідність дослідження проблем не тільки формування, але й реалізації конкурентоспроможності робочої сили, пов'язаних з посиленням інноваційних засад суспільного розвитку.

Метою статті $\epsilon$ дослідження проблем формування та реалізації конкурентоспроможності робочої сили з урахуванням впливу інноваційних чинників, визначення напрямів реалізації конкурентних переваг робочої сили в умовах трансформаційних змін.

Виклад основного матеріалу. Динамічність трансформаційних змін глобалізованого світового економічного середовища, посилення значення інноваційних чинників розвитку обумовлюе необхідність покращення якості робочої сили. Досягнення високого рівня конкурентоспроможності національних економік за рахунок мобілізації чинників ефективності та інноваційності можливо на основі підготовки та використання конкурентоспроможної робочої сили, створення умов для реалізації іiі конкурентних переваг на внутрішньому та зовнішньому ринках праці.

Це передбачає необхідність дослідження проблем отримання та реалізації конкурентних переваг робочої сили. Країни можуть отримати статус «лідерівінноваторів», згідно точки зору М. Портера, за рахунок реалізації набутих фірмами конкурентних переваг, які грунтуються на постійно здійснюваних інноваціях та оновленні технологій [6]. Н. Хоффман, аналізуючи проблеми досягнення та реалізації конкурентних переваг, визначає їх як достатньо унікальні особливості (властивості), володіння якими забезпечує отримання переваг (виграшів), порівняно 3 конкурентами, протягом достатньо тривалого проміжку часу [7]. При цьому конкурентні переваги можуть бути отримані двома способами:

1) ціноовии (зниженням цін на товари, послуги, порівняно з цінами на товари, послуги подібної якості);

2) неціновими (забезпеченням більш високої якості товару, порівняно з якісними характеристиками аналогічних за цінами товарів, послуг).

Специфіка формування та реалізації конкурентних переваг робочої сили обумовлена особливостями характеру та змісту праці, у процесі якого використовуються споживчі якості робочої сили. Формування конкурентних переваг робочої сили пов'язано, передусім, не тільки з існуючим демографічним, трудовим та соціальним потенціалами окремих індивідів та населення у цілому, але й можливостями їх ефективного використання та розвитку. При цьому реалізація набутих у процесі життєдіяльності переваг повинна забезпечувати суб'єктам конкуренції перевагу над наявними або потенційними конкурентами.

Водночас слід зазначити, що конкурентоспроможність робочої сили та можливості її підвищення визначаються якісними характеристиками робочої сили, іiї споживчими властивостями та ціною, різні комбінації яких формують конкурентні переваги робочої сили [8]. Переважна більшість науковців при дослідженні економічної сутності поняття «конкурентоспроможність робочої сили» підкреслює необхідність забезпечення відповідності якості робочої сили вимогам ринку, можливість перемагати в конкуренції на ринку праці, тобто «повніше порівняно 3 іншими кандидатами 
задовольняти вимоги роботодавців за рівнем знань, вмінь, навичок, особистих якостей» [9, с. 122]. При цьому науковці наголошують на тому, що конкурентоспроможність працівників може бути визначена як їх «готовність та спроможність в умовах конкурентної боротьби реалізувати конкурентні переваги на основі забезпечення відповідності характеристик робочої сили вимогам робочих місць та потребам економіки» [8].

Еволюція змін процесу формування та розвитку конкурентоспроможності робочої сили свідчить про існування певних закономірностей. Для індустріальної та постіндустріальної моделей економік було характерно підвищення попиту на кваліфікованих робітників з інструментом, трудова діяльність яких була спрямована на виконання регламентованих операцій по обслуговуванню технологічного устаткування. Відповідно, конкурентні переваги отримувалися, передусім, працівниками, здатними до навчання та підвищення кваліфікації, що результувалися в освоєнні прогресивних форм організації праці. Пріоритетного значення на етапах економічного розвитку, які характеризувалися значними циклічними та кон'юнктурними змінами, набували саме цінові конкурентні переваги робочої сили, пов'язані з можливостями зниження вартості та ціни робочої сили в умовах обмеженого попиту з боку роботодавців.

Перехід до інформаційної моделі економіки супроводжувався посиленням ролі інноваційних технологій, що потребувало залучення знаннєвоємної праці. Початок глобальної трансформації (Четвертої промислової революції), яка, на думку експертів World Economic Forum, характеризується конвергенцією цифрових, фізичних i біотехнологій, спрямованою на зміни способів виробництва, споживання, спілкування, переміщення, генерування енергії та комунікації між людьми, принципово змінює сферу праці, геополітичне безпекове середовище, соціальні цінності та етичні норми [10]. Відповідно, відбуваються зміни у характері праці, пов'язані 3 швидкою «інформаціоналізацією» суспільства, поширенням нестандартних форм зайнятості, зміною концептуальних підходів до традиційної праці.

Посилення ролі творчого характеру праці в умовах інноваційних змін (при одночасному зниженні значимості жорстко регламентованої, уніфікованої праці) обумовлює відповідні зміни у співвідношенні способів отримання конкурентних переваг. Домінуючими поступово стають нецінові конкурентні переваги робочої сили, отримані за рахунок забезпечення більш високої іiі якості (насамперед, підвищення рівня освіти, кваліфікації, оволодіння сучасними навиками). Реалізація цих конкурентних переваг в умовах прискорення технологічного розвитку потребує постійного удосконалення освітньо-кваліфікаційних характеристик робочої сили шляхом систематичного оновлення знань, умінь та навичок працівників на основі безперервної освіти.

Однак можливості формування та реалізації конкурентних переваг робочої сили залежать не тільки від створення умов для покращення іiі якості, підвищення кваліфікації, але й наявності ефективних робочих місць та вакансій. Обмежені перспективи створення ефективних, конкурентоспроможних робочих місць суттєво звужують можливості реалізації конкурентних переваг робочої сили, пов'язаних 3 покращенням їі якісних параметрів.

Не менш важливим $є$ вплив на реалізацію конкурентних переваг робочої сили співвідношення попиту та пропозиції на ринку праці. За умов скорочення обсягів попиту на робочу силу (з боку роботодавців) посилюється конкуренція між пошукувачами робочих місць (працівниками). Це, відповідно, стимулює пошукувачів до активації існуючих та акумулювання додаткових конкурентних переваг. При цьому 
співвідношення між ціновими та неціновими складовими конкурентних переваг залежить від сили конкуренції в окремих сегментах ринку праці як з боку роботодавців, так і працівників. У разі посилення конкуренції між пошукувачами за отримання робочого місця можливе застосування практики т.зв. «демпінгування», в результаті якого працівники погоджуються виконувати роботу за невисокий рівень оплати праці, не зосереджуючись на покращенні іï якості.

Відповідно, працівник може отримувати конкурентні переваги за рахунок або більш високої якості робочої сили (при утриманні постійного рівня цін), або зниження ціни (при збереженні достатньо стабільних параметрів якості). Однак оскільки ціна товару «робоча сила» на ринку праці має тенденцію до вирівнювання, то більш прийнятним варіантом для підвищення конкурентоспроможності робочої сили може стати поліпшення iі якості. Недостатньо високий рівень професійно-кваліфікаційної мобільності значно звужує функціональні можливості працівників, може ускладнювати реалізацію конкурентних переваг у ході конкурентної боротьби за робочі місця. Натомість, посилення адаптаційних можливостей фахівців, обумовлене наявністю фундаментальної підготовки, універсалізацією працівників стають необхідною передумовою підвищення рівня їх професійно-кваліфікаційної мобільності, що сприятиме зростанню конкурентоспроможності.

За умов збільшення попиту на робочу силу (посилення мотивації роботодавців до виробництва більш конкурентних товарів / послуг) можливе посилення конкуренції між ними за найм працівників, що мають більш значні конкурентні переваги. У цьому випадку роботодавці, зацікавлені у наймі кваліфікованої робочої сили, здатної обслуговувати сучасні технології, пропонують більш високий рівень оплати праці. Конкурентні позиції роботодавців на ринку праці визначаються, насамперед, рівнем оплати праці, що пропонується ними. Цінова конкуренція при цьому передбачає підбір необхідної робочої сили за рахунок маніпулювання рівнем витрат на ії найм, залучення підприємцем висококваліфікованих спеціалістів за рахунок більш високого рівня оплати праці, що пропонується.

Посилення конкуренції між роботодавцями за найм кваліфікованої робочої сили може стимулювати їх до удосконалення форм організації виробництва або за рахунок інвестування в оновлення технологічних процесів, або за рахунок удосконалення організаційних умов діяльності працівників. При цьому конкурентоспроможність роботодавців на ринку праці залежить не тільки від фінансово-економічних можливостей технічного переозброєння робочих місць, але й від обгрунтованості розрахунків термінів окупності інвестицій, спрямованих на залучення високопрофесійних фахівців.

Зниження рівня монополізації ринку праці об'єктивно супроводжується універсалізацією працівників, що посилює їх адаптованість до нових умов трудової діяльності. Забезпечення конкуренції на ринку праці як дієвого регулятора співвідношення попиту та пропозиції на ринку праці, стимулює працівників до підвищення рівня кваліфікації, з одного боку, та роботодавців - до покращення якості робочих місць, з іншого боку. Однак при цьому слід враховувати, що існування недобросовісної конкуренції на ринку праці, яка мінімізує шанси отримання рівного доступу до роботи для усіх категорій населення, суттєво звужує можливості реалізації конкурентних переваг та дестимулюючим чином впливає на мотивацію працівників до подальшого пошуку відповідної роботи.

В умовах кон'юнктурних змін на ринку праці можливості формування конкурентоспроможної робочої сили та реалізації ії конкурентних переваг залежать від 
впливу різноспрямованих або односпрямованих чинників, врахування дії яких може забезпечити результативність цього процесу. При цьому слід враховувати як ризикизагрози, так і ризики-можливості формування та реалізації конкурентоспроможності робочої сили, пов'язані з впливом демографічних, техніко-організаційних, соціальноекономічних, освітньо-професійних та особистісно-мотиваційних чинників (Рис. 1)

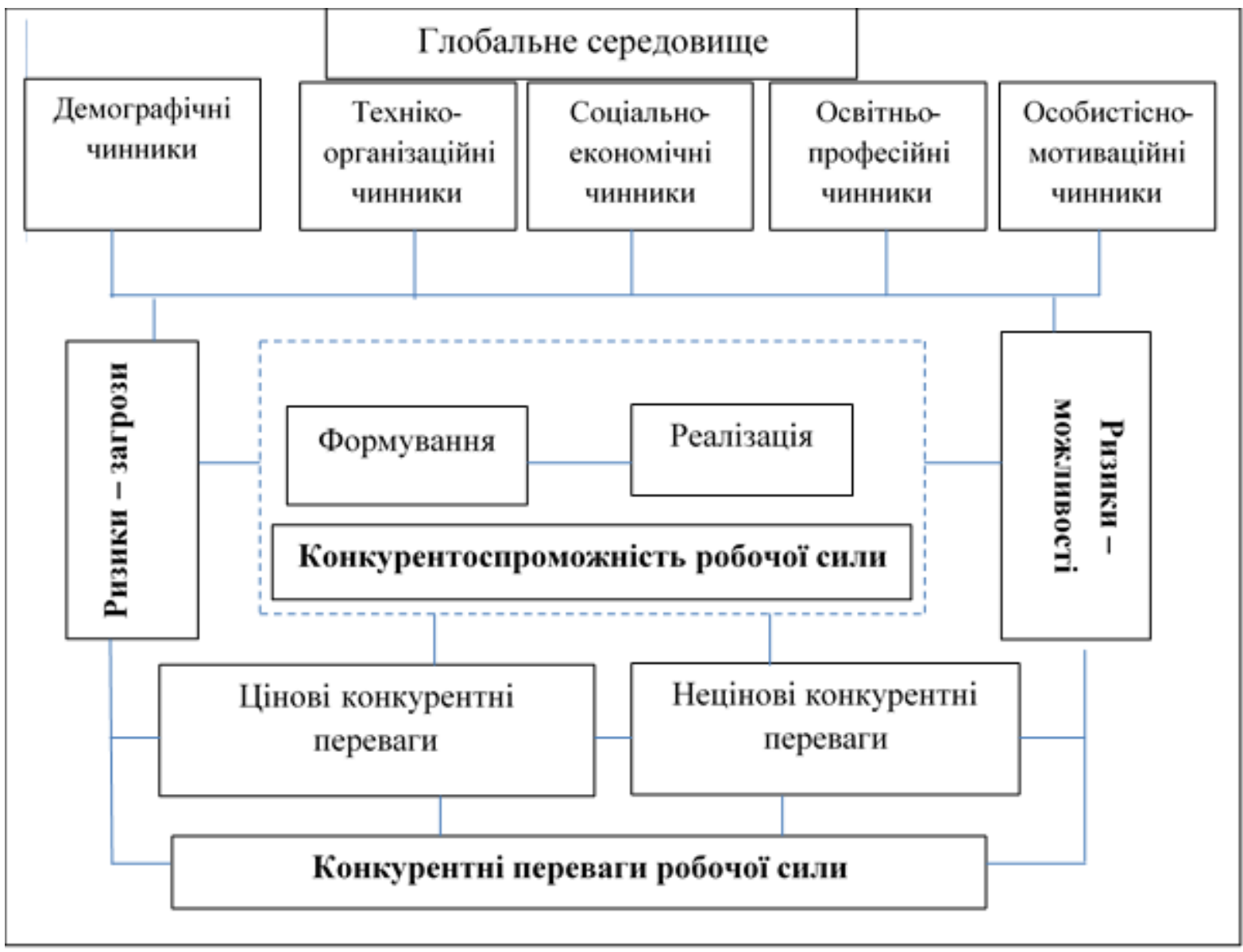

Рис. 1. Структурно-логічна схема формування та реалізації конкурентоспроможності робочої сили

Критично важливо визначити умови трансформації ризиків у загрози: причому це стосується не тільки умов формування конкурентоспроможності робочої сили (отримання цінових або нецінових конкурентних переваг), але й можливостей реалізації цих переваг у ході конкурентної боротьби за робочі місця. Водночас слід враховувати, що трансформація ризиків формування конкурентоспроможності робочої сили та реалізації іiі власних конкурентних переваг у загрози, як і можливості підвищення конкурентоспроможності загалом залежать від вектору та ступеню впливу демографічних, техніко-організаційних, соціально-економічних, освітньо-професійних та особистісно-мотиваційних чинників.

Результативність реалізації конкурентних переваг робочої сили, спрямованих на підвищення ії конкурентоспроможності, обумовлена впливом демографічних чинників. Обсяги пропозиції робочої сили залежать, передусім, від демографічної ситуації, яка формується в результаті впливу чинників як екзогенного, так і ендогенного характеру. Звуження демографічного базису відтворення населення України супроводжується 
наростанням ризиків, пов'язаних з постарінням населення. Зниження народжуваності (навіть зважаючи на запровадження ряду пронаталістських заходів [11]) призводить до відповідних змін демографічного навантаження на населення у віці 16-59 років. Зокрема, у 2016 р. спостерігалося зменшення цього навантаження з боку дітей (у віці 015 років) - до 265 осіб, при відповідному збільшенні з боку населення у віці 60 років і старше - до 367 осіб [12]. Розрив між Україною та країнами Європейського Союзу за показником очікуваної тривалості життя та іншими параметрами дожиття населення останнім часом також збільшується. Зокрема, очікувана тривалість життя при народженні в Україні становила у 2015 р. 66,4 роки - у чоловіків та 76,3 роки - у жінок. При цьому тривалість життя чоловіків в Україні була нижчою на 14 років, ніж у Швеції, та майже на 7 років, ніж у Польщі [12].

Міграційні процеси також суттєвим чином впливають на конкурентоспроможність робочої сили, обмежуючи обсяги іiї пропозиції. За результатами модульного вибіркового обстеження населення (домогосподарств) із питань трудової міграції, проведеного органами державної статистики у січні-червні 2017 року, кількість трудових мігрантів у 2015-2017 рр. становила 1303,3 тис. осіб. Причому у складі мігрантів домінували представники найбільш економічно активних груп населення [13]. Також серйозною проблемою для України може стати втрата значного освітнього потенціалу молоді внаслідок міграції для навчання та працевлаштування за кордоном. За результатами проведеного аналітичним центром CEDOS моніторингу кількості українських громадян, що навчаються у зарубіжних університетах, у 2014/2015 навчальному році 59648 громадян України навчалися за кордоном (з них переважна більшість у Польщі, Німеччині, Росії, Канаді, Італії, Чеській Республіці, США та ін.) [14].

Відповідно, погіршення демографічної ситуації в країні, збільшення міграційного відтоку найбільш продуктивних груп населення може призводити до трансформації демографічних ризиків у загрози, ускладнює вирішення завдання підвищення конкурентоспроможності робочої сили.

Необхідно відзначити, що реалізація конкурентних переваг робочої сили, спрямованих на підвищення іiі конкурентоспроможності, залежить також від впливу техніко-організаційних чинників. Наростання ризиків, пов'язаних з впливом таких чинників як повільні темпи структурної перебудови економіки України, обмежена кількість високотехнологічних робочих місць, слабка мотивація роботодавців до технологічного оновлення виробничих процесів ускладнюють можливості реалізації нецінових конкурентних переваг робочої сили. Дотепер інноваційна активність економіки залишається невисокою: протягом 2014-2016 pp. частка інноваційно активних підприємств становила лише 18,4\% від загальної кількості обстежених підприємств [15]. Відповідно, обмежені можливості генерації та впровадження інновацій також ускладнюють можливості реалізації нецінових конкурентних переваг робочої сили, ослаблюють мотивацію до покращення якісної складової конкурентоспроможності.

Не менш важливим соціально-економічним чинником впливу на підвищення конкурентоспроможності робочої сили в Україні є заниження вартості робочої сили, слабкість кореляції між рівнем кваліфікації працівників та рівнем доходів від зайнятості, надмірна соціалізація політики доходів в Україні. Превалювання моделі «дешевої» робочої сили в Україні протягом останніх десятиріч призвело до консервації низького рівня заробітної плати (порівняно 3 переважною більшістю європейських країн). За даними МОП, середній рівень заробітної плати в Україні у 2016 році 
становив 767 \$ (constant 2011 PРP), порівняно з 2264 \$ (constant 2011 РPР) у Польщі, 2053 \$ (constant 2011 РPР) в Угорщині, 2235 \$ (constant 2011 PРP) у Чеській Республіці [16]. За даними Державної служби статистики України, частка витрат на персонал підприємств (витрат на оплату праці та соціальні заходи підприємств) у собівартості реалізованої продукції (товарів, робіт, послуг) на великих підприємствах скоротилася 3 3,74\% у 2014 році до 3,36\% у 2016 р. [17]. Економіка, що базується на низькій вартості робочої сили, не гарантує розширення внутрішнього споживчого попиту, не забезпечує високих стандартів споживання, звужує можливості якісного відтворення робочої сили, провокує відплив найбільш ініціативних економічно активних громадян до інших країн, дестимулює зростання продуктивності праці та призводить до погіршення якості людського капіталу [18].

Серед освітньо-професійних чинників, що суттєво впливають на ризики формування та реалізації конкурентоспроможності робочої сили, можна виокремити також освітньо-професійну структуру зайнятості. Збереження індустріального (екстенсивного) типу зайнятості характеризується диспропорціями між рівнями освіти та вимогами працівників до умов найму та оплати праці, з одного боку, та потребами економіки у робочій силі за професіями та кваліфікаціями, з іншого. Достатньо поширеним $є$ феномен т.зв. «надлишкової кваліфікації» («вертикальна кваліфікаційна невідповідність»), коли отриманий рівень освіти перевищує рівень вимог до обслуговування робочого місця [19]. Водночас значною залишається частка зайнятих за масовими професіями вузького профілю. За даними обстеження економічної активності населення у 2017 році, частка представників найпростіших професій у структурі зайнятого населення становила 19,4\%. Натомість, питома вага професіоналів у загальній чисельності зайнятого населення становила 17,9\%, фахівців - 11,3\%, що, відповідно, свідчить про збереження ресурсоємної структури зайнятості [20].

Разом 3 тим, достатньо слабкими залишаються стимули до підвищення професійного рівня зайнятого населення, що значно загострює ризики-загрози формування та реалізації конкурентоспроможності робочої сили. Зокрема, результати обстеження «Перехід молоді від навчання до стабільної роботи», проведеного у 2015 році Українським центром соціальних реформ, Інститутом демографії та соціальних досліджень імені М.В. Птухи НАН України, Центром соціального моніторингу, за сприяння Міжнародної організації праці, The Mastercard Foundation, "Work4Youth" свідчать, що дотепер невисокою залишається націленість молоді на продовження освіти / професійної підготовки у перспективі. Зокрема, традиційно зорієнтованими на продовження навчання є представники вікової групи $15-19$ років $(53,9 \%)$. Водночас достатньо загрозливою залишається ситуація з мотивацією навчання молоді у віці 25-29 років щодо продовження навчання (майже 60,9\% відзначили, що не бажають іiі продовжувати) [21].

Особистісні риси людини (креативність, творчий підхід до вирішення поставлених завдань, новаторство) також виступають важливими передумовами посилення готовності до підвищення власної конкурентоспроможності. Однак готовність до оновлення знань, підвищення професійно-кваліфікаційного рівня, до участі в інноваційної діяльності залежить передусім від мотиваційних настанов особистості. Згідно результатам національних щорічних моніторингових опитувань «Українське суспільство 1992-2016 рр. Стан та динаміка змін. Соціологічний моніторинг», проведених Інститутом соціології НАН України, у 2016 році майже 78,7\% респондентів відзначили важливість підвищення освітнього рівня (порівняно з 70,9\% у 2014 р.) [22]. Це свідчить про поступову зміну пріоритетів у рейтингу ціннісних 
орієнтацій людей, збільшення націленості на отримання конкурентних переваг, пов'язаних 3 покращенням якісних характеристик. Водночас важливим $\epsilon$ вплив об'єктивних чинників, зокрема, ступеню розвиненості інституційного середовища, що забезпечуватиме реалізацію мотиваційних настанов на підвищення кваліфікаційного рівня.

Висновки та перспективи подальшого дослідження. Загалом, усі зазначені вище чинники суттєво впливають на формування та реалізацію конкурентоспроможності робочої сили, визначаючи траєкторію їх змін з урахуванням впливу інноваційних чинників розвитку. 3 метою запобігання трансформації ризиків формування та реалізації конкурентоспроможності робочої сили, пов'язаних із звуженням демографічного базису, погіршенням освітньо-професійної структури зайнятості внаслідок технологічної застарілості виробничих процесів, низької інноваційної активності економіки, утримання неконкурентної заробітної плати, у загрози, доцільно реалізовувати наступні заходи:

- сприяти проведенню структурних реформ в економіці, спрямованих на забезпечення реструктуризації зайнятості, переходу до інноваційної моделі розвитку на основі інформатизації суспільства, технологічного оновлення виробництва;

- розробити та впроваджувати заходи державної політики у демографічній сфері, спрямовані на поліпшення якості життя населення, зниження рівня смертності населення працездатного віку, мінімізації втрат від зростання захворюваності, утримання значної частки робочих місць 3 шкідливими умовами праці; активізації пропагування здорового способу життя;

- удосконалювати державну політику в освітній сфері у напряму досягнення освітньо-кваліфікаційної збалансованості, покращення якості освітніх послуг;

- забезпечувати нормативно-правове забезпечення інституційних реформ, пов'язаних із забезпеченням гідних умов найму та оплати праці; посиленням взаємозв'язку між рівнем кваліфікації та доходів від зайнятості;

- стимулювати активізацію поведінкових стратегій населення, спрямованих на підвищення конкурентоспроможності робочої сили на основі реалізації конкурентних переваг, пов'язаних 3 поліпшенням якісних характеристик. В якості перспектив подальших досліджень доцільно розроблення механізму забезпечення реалізації конкурентних переваг робочої сили, дослідження синергетичного ефекту від дії усіх чинників впливу на формування та реалізацію конкурентоспроможності робочої сили.

\section{СПИСОК ВИКОРИСТАНИХ ПОСИЛАНЬ}

1. For a European Industrial Renaissance (2014). Communication from the Commission to the European Parliament, the Council, the European Economic and Social Committee and the Committee of the Regions. Luxembourg: Office for Official Publications of the European Communities. - Last access: 2014. - Title from the screen: http://eur-lex.europa.eu/legalcontent/EN/TXT/PDF/?uri= CELEX:52014DC0014\&from=EN

2. A Skilled Workforce for Strong, Sustainable and Balanced Growth: A G20 Training Strategy (2010). - Geneva: International Labour Office. - Last access: 2010. - Title from the screen: https://www.oecd.org/g20/summits/toronto/G20-Skills-Strategy.pdf

3. Albrecht, James and Susan Vroman (2002): A Matching Model with Endogenous Skill Requirements. International Economic Review, vol. 43, No. 1, February 2002. - Last access: 2002. - Title from the screen. https://onlinelibrary.wiley.com/doi/abs/10.1111/1468-2354.t01$\underline{1-00012}$ 
4. Vanhala, J. (2007) Essays on Labor Market Frictions, Technological Change and Macroeconomic Fluctuations. Research Reports Kansantaloustieteen laitoksen tutkimuksia, No. 108:2007 - Last access: 2002. - Title from the screen: http://ethesis.helsinki.fi/julkaisut/val/kansa/vk/vanhala/essayson.pdf

5. Штундер I.О. Ефективна зайнятість: реалії та інноваційні перспективи: моногр. / I.O. Штундер. - Київ : Університет економіки та права «КРОК», 2016. - 392 с.

6. Porter, Michael E. (1998) Competitive Advantage: Creating and Sustaining Superior Performance: with a new Introduction New York: The Free Press. - Last access: 2005. - Title from the screen: https://trove.nla.gov.au/version/8667868

7. Hoffman, Nicole P. (2000). An Examination of the "Sustainable Competitive Advantage" Concept: Past, Present, and Future, Academy of Marketing Science Review, v 2000 (4). - Last access: 2014. - Title from the screen: http://citeseerx.ist.psu.edu/viewdoc/ download?doi=10.1.1.200.7948\&rep=rep1\&type=pdf

8. Войналович I.А. Освітній компонент конкурентоспроможності робочої сили як інноваційний чинник iї підвищення / I.А. Войналович // Вісник Хмельницького національного університету. Науковий журнал. / Економічні науки. - №5. - Т. 2. Хмельницький: ХНУ, 2009. - С. 26-30

9. Грішнова О.А. Формування якості робочої сили та конкурентоспроможності працівника в процесі інвестування в людський капітал / О.А. Грішнова // Конкурентоспроможність у сфері праці: Збірник наукових праць Інституту економіки НАН України. Серія «Економіка праці та соціальної сфери». - Випуск 1. - Київ, 2001. $163 \mathrm{c}$.

10. Global Competitiveness Report-2016-2017. - Last access: 2005. - Title from the screen: https://www.weforum.org/reports/the-global-competitiveness-report-2016-2017-1

11. Населення України. Народжуваність в Україні у контексті суспільнотрансформаційних процесів. - К.: АДЕФ-Україна, 2008. - 288 с.

12. Населення України за 2016 рік. Демографічний щорічник. Державна служба статистики України, 2017. [Електронний ресурс]. - Режим доступу: http://www.ukrstat.gov.ua/druk/publicat/kat_u/2017/zb/12/ naselen2016w.zip

13. Зовнішня трудова міграція населення (за результатами модульного вибіркового обстеження). Статистичний бюлетень Державної служби статистики України, 2017. [Електронний peсурc]. - Режим доступу: http://www.ukrstat.gov.ua/druk/ publicat/kat_u/2017/bl/12/bl_ztm_2017_w.zip

14. Українські студенти за кордоном: скільки та чому? Олександра Слободян, Єгор Стадний // 13.12.2016 p. [Електронний ресурс]. - Режим доступу: https://cedos.org.ua/uk/osvita/ukrainski-studenty-za-kordonom-skilky-ta-chomu

15. Експрес-випуск «Обстеження інноваційної діяльності в економіці України за період 2014-2016 років» (без урахування тимчасово окупованої території Автономної Республіки Крим, м. Севастополя та частини зони проведення антитерористичної операції) від 6.10.2017. - [Електронний ресурс]. - Режим доступу: http://www.ukrstat.gov.ua/express/expr2017/05/90_w.zip

16. Monthly earning. ILO Stat data - Last access: 2017. - Title from the screen: http://www.ilo.org/ilostat/faces/oracle/webcenter/portalapp/pagehierarchy/Page3.jspx?MBI_I $\mathrm{D}=435$

17. Діяльність суб’єктів великого, середнього, малого та мікропідприємництва за 2016 рік. Статистичний збірник //Державна служба статистики України. [Електронний ресурс]. - Режим доступу: http://www.ukrstat.gov.ua/druk/publicat/kat_u/ 2017/zb/12/zb_dsvsm 2016pdf.zip 
18. Людський розвиток в Україні. Інноваційні види зайнятості та перспективи їх розвитку: моногр.) / за ред. Е.М. Лібанової // Ін-т демографії та соціальних досліджень ім. М.В. Птухи НАН України. - К., 2016. - 328 с.

19. Skills mismatch experimental indicators. Eurostat. - Last access: 2017. - Title from the screen: https://ec.europa.eu/eurostat/ web/skills/background/experimental-statistics

20. Економічна активність населення України у 2017 році. Стат. збірник / Державна служба статистики України, 2017. - [Електронний ресурс]. - Режим доступу: http://www.ukrstat.gov.ua/druk/publicat/kat_u/2018/zb/07/zb_eanu2017w.zip

21. Перехід на ринок праці молоді України: результати міжнародного дослідження «School-to-work transition surveys» в Україні у 2013 та 2015 роках / Елла Лібанова, Олександр Цимбал, Олег Ярош. - [Електронний ресурс]. - Режим доступу: http://www.idss.org.ua/monografii/2016_SDGs_Ukraine_ua.pdf 